\title{
The Role of Design in the World Perception
}

\author{
Irina Denisova \\ Russian State Specialized Arts Academy \\ Moscow, Russia \\ e-mail: i-deni@yandex.ru
}

\begin{abstract}
This article is dedicated to different kinds of design and their connection with arts, science and technical progress. The role of design in the human and vision formation is considered. Interaction of aesthetic, emotional, historical and organizational human perception of the environment is discovered.
\end{abstract}

Keywords-world vision; arts synthesis; space organization; system of things; environment; cultural traditions

\section{THE HISTORY OF DESIGN}

Design is a form of a project-artistic activity. The role of design is difficult to overestimate, since there's actually no kind of activity which does not involve design. Objects become designer's communication means. The main human basic means are decorated by design, hence why they are widely available to a general viewer. Yet the project-artistic activity can be considered on a much wider scale, concerning the whole society. According to an opinion of one of the leading design historians, Arthur Pulos, «The United States became the first projected nation. It was born as a result of human activity of the people who extracted a problem and then solved it for mutual benefit. America didn't come from God knows where - it was projected».

But even before the project-artistic activity, before scientific technologies and mass production, before extracting the problems and their solution for mutual benefit during many millenniums, a human being was accompanied by a great number of items - created by him. The material culture of ancient Egypt and the Antiquity times is sometimes called proto-design time. Such notion may be used for cave pictures definitions.

What did our ancient ancestors think when decorated the stone walls of their caves? Was it a wish to make them more comfortable? Maybe. Or maybe it was a wish to have a successful hunt, and pass this experience to the future generations. The Medieval craftsman painted a jug with love and care? Why does he do it, if he can keep water in a common one.

The answer is obvious: everyone is looking for emotive expression, and trying to create new forms of expression. Changing epochs change people with their feelings and thoughts. The final aim of a prehistoric artist and a Medieval craftsman is the decoration of his environment.
A modern human does not ambush, nor runs with a spear looking for a catch. He can buy both meat and a jar in the same supermarket. But all these cave decorations and jars are like precious pearls; historic documents showing some light on the life of lost generations. For this traditional appearance it is necessary to reveal a reflected connection to the past - hence why modern design artists turn to their predecessors in their search.

Modern design is a synthesis of arts, science and technical progress. The changes in one area cause the changes in the other. Rapid industry development of the XIXth century opened new opportunities to the human discovery of the environment. Metal constructions appearance caused the new construction techniques; machines implementation caused mass production, which demanded technological simplicity. Metal usage, forms and elements standardization became reasons for combined systems usage — the famous Chrystal Palace (1851) appeared in London and the Eiffel tower (1889) in Paris.

\section{THE EIFFEL TOWER}

Today we can't imagine Paris without this iconic structure, without this lace art object. It is difficult to believe that Eiffel himself was afraid at first to offend public taste by building this uncompromisingly naked construction in the center of Paris. The public taste was really offended by this «sticking up» 300 meter high tower. The head of the exhibition committee was handed a protest: «We, writers, artists, sculptors and architects express our indignation by this unnecessary and monstrous Eiffel tower being built in the heart of the capital». Among the people who signed it were Guy de Maupassant, Charles Hugo, Alexander-Dumasson and many other art activists - about 300 people.

But several decades later industrial revolution crashed the previous static perception of architecture, which had been kept from the Renaissance times; suddenly a content of the architectural image of the Eiffel tower was discovered. This environmental object became the city's and the country's symbol. The Eiffel tower inspired many poets and artists for creation of outstanding works. It is a good example of the great importance that an emotional side may have on interaction of science, art, architecture and construction. It is also the best example of a great design role in aesthetic education of the whole generation and creation of the new cultural traditions. 


\section{SUPPLY AND DEMAND}

Modern design was long ago divided into; graphic, information, commercial, and environmental - among others. We'll consider the role of graphic design in the vision forming on the Russian example, in the first years after the Revolution and the Civil War.

In the 1920's the main design areas were publishing business, graphics, book design and graphic design in general. A cultural revolution followed the social one, one of the main tasks of which was illiteracy liquidation. It was publishing businesses with their pre-Revolutionary traditions of book printing that appeared to be the most developed in comparison to others.

Propaganda of books, knowledge, and literacy was held everywhere. Fiction, scientific works, technique, and illustrated magazines were issued in high circulation. The Soviet commercial advertising and applied graphics told the world about some unknown life, in which text-books, overshoes «galoshi» and rubber nipples for children were advertised. The new technique and state leaders portraits were placed on sweets wrappers and matchboxes.

All this advertising production demanded new designer solutions. A special placard department of the Russian Telegraph Agency (ROSTA) began working in 1919. The placards were made by hand and were exhibited in shop windows, railway stations, at propaganda points and other public places. At the beginning of October of 1919 Vladimir Mayakovsky started his work in the ROSTA Windows. He changed its structure, subjected its texts and pictures to the same topic; the placards were satiric and were dedicated to the current events. Brief poems of the ROSTA Windows were characterized by simplicity and sharpness, which came from folk songs and poems. Mayakovsky`s talent as a dramatist found his way here.

The Windows were issued in the years of the Russian Civil war and foreign intervention, and also during industrialization. Its specifics were characterized by immediate reaction to the most acute issues and facts. A particular type of the characters was traveling from one placard to another: a worker, a Red Army soldier, a peasant, a capitalist, a priest, and a «fist». The characters were easily recognized and the thoughts were easily understood. The Windows were trusted. For the pauper illiterate Russia it was one of the only sources of information. As an original form of the mass art, ROSTA Windows played a considerable role in the Soviet culture and the new design traditions.

\section{TYPES OF DESIGN AND THEIR EFFECTS}

In industrial or technical design a large scale of research, which is fulfilled by sociologists, psychologists, engineers, and designers, precedes every development. The last have the role of project coordination.
One of the first world designers, who implemented the idea of complex approach into life, was Raymond Louis. In 1975 he was included into the number of Americans who «influenced greatly the country's history and comfort». Louis's slogan was «to notice the bad, to improve and to sell». Advertising is the motor of commerce and in our time of communications and new technologies it is a progress motor.

A common Goldspot fridge brought glory to Louis. The fridge got a modern industrial form for the first time and was completely covered by snow-white enamel, where chrome details and handles shone out. Besides, Louis changed the interior planning, which considerably improved temperature conditions of the freezer and made the choice even more comfortable. This model broke all the records.

A model of a complex approach to design may be considered a new image of Shell Company. Not only a logotype was created, but also new uniform was designed for the personnel, and the architecture of the stations was thought over. The result of Louis's rebranding was a considerable increase in the competitive ability of the company. Its production is still being sold in different countries around the world. Besides, Louis developed living bays for the American space shuttles Apollo, Skylab, and Shuttle. It was he who developed the famous Coca-Cola logo, as well as logos for the Pennsylvania locomotive and the Knorr dry soup package.

Garden design as a rule reflects its lifestyle combining a human being with its dwelling place. For creation of this or that interior it is important to feel the environment in which a person is living. It will help a designer to create the atmosphere in which a person would feel comfortably.

Thus, design structures the space, accentuating particular objects and helping to understand space as a whole system. Finally, it impacts people's feelings and emotions. Creating items and systems design organizes the world, people's behavior, emotions and feelings. This is another design function - organizational one. A special function is acquired by the organization of exhibition halls, trade centers, supermarkets, offices, and in all mass spaces.

\section{CONCLUSION}

The role of design in perception and forming of the vision increases annually. Harmonic design becomes an important condition of competitive advantage in modern market relationship. Design becomes not only an aesthetically important expression of material and spiritual human life, but also an instrument for society management and control. It forms a valued picture of the world, upkeeps traditions, forms new tendencies and disturbs it. By being unique and powerful, and by effectively disturbing the aesthetic of society, design creates a personality; filled with respect and dignity, and opening new ways of selfperfection and of the environment. 


\section{REFERENCES}

[1] Bystrova T.Yu. An item. Form, Style. Introduction to design Philosophy. Ekaterinbourg, 2001.

[2] Glasychev V.L. On design. Moscow, 1970.

[3] Morosova N.N. Design pholosophy: social-antropologic problems. Ekaterinbourg, 2001.

[4] Donshin A.F. Design Humanist Essence. ULR: http:// atheismru.narod.ru/humanism/journal/38/donshin.htm

[5] Glazichev V.L.Design as It Is. ULR: http:// www.soob.ru/n/2006/3/2/0

[6] Gogueva V.P. Design as a Social-Cultural Phenomenon. Vestnik of the North Caucasus STU, 2004, 32. 